\title{
DOPPLER ULTRASOUND AND COMPUTED TOMOGRAPHY FINDINGS IN GALLSTONE ILEUS
}

\author{
Miguel-Angel Reyes-Caldelas', Fernanda Santiago-Roman 2, \\ Maria-del-Carmen Garcia-Blanco 1, Ernesto Roldan-Valadez 3, 4 \\ 1 - Radiology department, Hospital Angeles Acoxpa. Mexico City, Mexico. \\ 2 - Faculty of Human Medicine. Universidad Autonoma de Chiapas. Mexico City, Mexico. \\ 3 - Directorate of Research, Hospital General de Mexico "Dr Eduardo Liceaga". Mexico City, Mexico. \\ 4 - I.M. Sechenov First Moscow State Medical University (Sechenov University), Department of Radiology. Moscow, Russia.
}

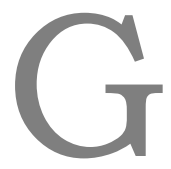

allstone ileus is a rare complication of gallstone disease, it causes bowel obstruction and achieves high mortality due to the predilected elderly patients and late diagnosis, for which different modalities of imaging are used.

Materials and methods. This case presents a 64-year-old man who developed this condition due to recurrent cholecystitis, diagnosed by ultrasound and CT scan, gallstone removed by surgery. Treatment is based on the patient's clinical status and should be sorted out according to comorbidities, hemodynamic stability, and surgical risk. Also a brief literature review is presented.

Keywords: cholelithiasis, gallstone, gallstone ileus, cholecystoenteric fistula, intestinal obstruction, enterolithotomy.

Corresponding author: Ernesto Roldan-Valadez, e-mail: ernest.roldan@usa.net

For citation: Miguel-Angel Reyes-Caldelas, Fernanda Santiago-Roman, Maria-del-Carmen Garcia-Blanco, Ernesto Roldan-Valadez. Doppler ultrasound and computed tomography findings in gallstone. REJR 2021; 11(4):164-168. DOI: 10.21569/2222-7415-2021-11-4-164-168.

Received: 23.09 .2021

Accepted:

02.12.2021

\section{УАЬТРАЗВУКОВОЕ ИССАЕАОВАНИЕ И КОМПЬЮТЕРНАЯ ТОМОГРАФИЯ ЖЕАЧНОКАМЕННОЙ НЕПРОХОАИМОСТИ}

\author{
Мигель-Анхель Рейес-Кальлелас' , Фернанла Сантьяго-Роман², \\ Мария-Аель-Кармен Гарсия-Бланко ', Эрнесто Ро^Аан-Ва^алес 3,4
}

1 - Отделение мучевой диагностики, больница Анхелес Акохпа. Мехико, Мексика.

2 - Факультет медицины человека. Автономный университет штата Чьяпас. Мехико, Мексика.

3 - Генеральная больница Мексики "Доктор Эдуардо Аисеага". Мехико, Мексика.

4 - Первый Московский государственньй медицинский университет имени И.М.Сеченова (Сеченовский университет), кафедра мучевой диагностики. Москва, Россия.

елчнокаменная непроходимость - редкое осложнение желчнокаменной болезни, при котором возникает непроходимость кишечника и приводит к высокой смертности из-за поздней диагностики и предрасположенности к ней пожилых пациентов. Для диагностики желчнокаменной непроходимости используются различные методы визуализации.

Материалы и методы. Представлен клинический случай мужчины, 64 мет, у которого желчнокаменная непроходимость развицась из-за рецидивирующего холецистита, диагностированного с помощью УЗИ и компьютерной томографии. Желчный камень удален хирургическим путем. Аечение основывается на клиническом состоянии пациента и должно быть согласовано в соответствии с сопутствующими заболеваниями, гемодинамической стабильностью пациента и 


\section{RUSSIAN ELECTRONIC JOURNAL OF RADIOLOGY}

потенциальными рисками от хирургического вмешатемьства. Также представлен краткий обзор митературы.

КАючевые слова: холелитиаз, желчный камень, желчнокаменная непроходимость, холецисто-кишечная фистула, кишечная непроходимость, энтеролитотомия.

Контактный автор: Эрнесто Роцдан-Валадес, e-mail: ernest.roldan@usa.net

Для иитирования: Мигель-Анхель Рейес-Кальделас, Фернанда Сантьяго-Роман, Мариядель-Кармен Гарсия-Бланко, Эрнесто Ролдан-Валадес. Ультразвуковое исследование и компьютерная томография желчнокаменной непроходимости. REJR 2021; 11(4):164-168. DOI: 10.21569/2222-7415-2021-11-4-164-168.

\section{Статья получена: $\quad 23.09 .2021 \quad$ Статья принята: $\quad 02.12 .2021$}

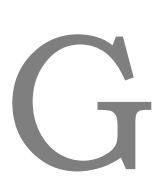

allstone ileus is an entity characterised by chronic episodes of lithiasiccholecystitis; the pressure effect, inflammation and ischemia from the offending gallstone or biliary sludge causes the erosion through the gallbladder wall, commonly, a cholecystoduodenal $(68 \%)$ or cholecystocholedochal fistula. The stone becomes impacted within the intestinal lumen; this typically occurs at the ileocecal valve $(73 \%)$, though the site of obstruction may also be the jejunum (14\%), colon $(4-8 \%)$ or duodenum $(5 \%)[1,2]$. It accounts for $1-4 \%$ of all bowel obstructions [3]. The associated mortality is estimated to be up to $30 \%$, attributed to elderly or frail population, multiple comorbidities, particularly cardiovascular, respiratory, and endocrine, and late presentation from the onset of symptoms (average 4-8 days) [3]. We displayan atypical presentation case of gallstone ileus with no pneumobilia, first diagnosed with ultrasound, later confirmed by CT scan, the macroscopic image of the gallstone in the operating room after surgical resection, and a brief review of the literature.

\section{Case presentation.}

A 64-years-old man was admitted to the emergency department complaining of one week of intermittent abdominal pain in epigastrium, which radiated to the back. He referred abdominal pain during previous months only treated with analgesics. Three days before admission, the patient referred seven emetic events of biliary characteristics. On physical examination, the patient presented abdominal distension, decreased peristalsis, and dullness in the right upper quadrant, with hepatomegaly, pain on palpation in the right upper quadrant, without peritoneal irritation.

Imaging evaluation included abdominal US (Ultrasound) that reported disseminated nonorganised gas that avoided gallbladder visualisation. A dilated small bowel with a big intraluminal stone with a $52.9 \mathrm{~mm} \times 34.3 \mathrm{~mm}$ size presented Twinkle artifact with Doppler US (Fig. 1A-D).
An abdominal non-enhanced CT scan revealed dilated stomach with gas within the gallbladder. Reformated images allowed visualisation of the cholecystoduodenal fistulae and small bowel stone (Fig. 2 A-D).

Initial management included fluid resuscitation, insertion of a nasogastric tube, analgesia and nil by mouth. Abdominal surgery was scheduled within 24 hours; a $5.2 \mathrm{~cm}$ gallstone was found in small bowel lumen, extracted by longitudinal enterolithotomy at distal ileum site (Fig. 3 AB).

He was discharged one week after surgery and continued his follow-up in the outpatient clinic and for the scheduling of a cholecystectomy with cholecystoduodenal fistula closure preferably 4-6 months after initial intervention.

\section{Discussion.}

Historical data.

Firstly, described in 1654 by Erasmus Bartholin, gallstone ileus (GI) has always been a rare cause of intestinal obstruction. The stone usually ulcerates through between the gallbladder and the duodenum, where it passes down into the small intestine, becoming impacted at the lower ileum. Wakefield, Vickers, and Walters (1939), in 141 post-mortem examinations, found the fistulous track in 101 cases $[4,5]$.

Clinical relevance of this report

Colonic obstruction from gallstone ileus is a rare complication of cholelithiasis, classically secondary to a cholecystocolonic fistula [1]. This case aims to draw attention towards gallstone ileus as a potential possibility for chronic abdominal pain; in this particular case, the diagnosis was delayed due to analgesics as a remedy for constant pain, complicating the case and putting the patient's life at risk.

\section{Imaging findings}

Blood tests at the time of presentation with gallstone ileus tend to be unremarkable, and the diagnosis is usually made with radiological imaging and reinforced by ultrasound [3]. Although 


\section{RUSSIAN ELECTRONIC JOURNAL OF RADIOLOGY}

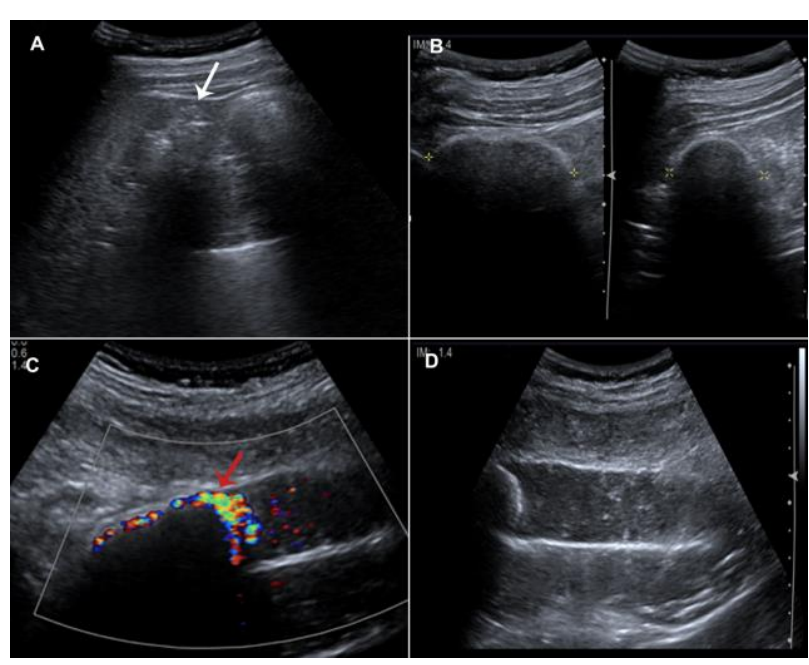

Fig. 1 (Рис. 1)

\section{Fig. 1. Ultrasound}

A - no gallbladder was identified, instead disseminated non-organised gas was identified (white arrow), B below the right lobe of the liver, dilated small bowel was noticed, tracking the possible site of obstruction; one big intraluminal stone with a size of $52.9 \times 34.3$ $\mathrm{mm}$. C - twinkle artifact in the stone surface when Color-Doppler (red arrow), D - the content of the dilated small bowel segment contained multiple small stones.

\section{Рис. 1. Ультразвуковое исслеАование.}

А - желчный пузырь не обнаружен, вместо него определяется диссеминированный неорганизованный газ (белая стрелка). В - книзу от правой доли печени визуализируются расширенные петли тонкого кишечника, указывающие возможное место обструкции; определяется один большой внутрипросветный камень размером 52,9х34,3 мм. С мерцающий артефакт на поверхности камня при цветном доплеровском режиме (красная стрелка). D - содержимое расширенного сегмента тонкой кишки содержит несколько мелких камней.

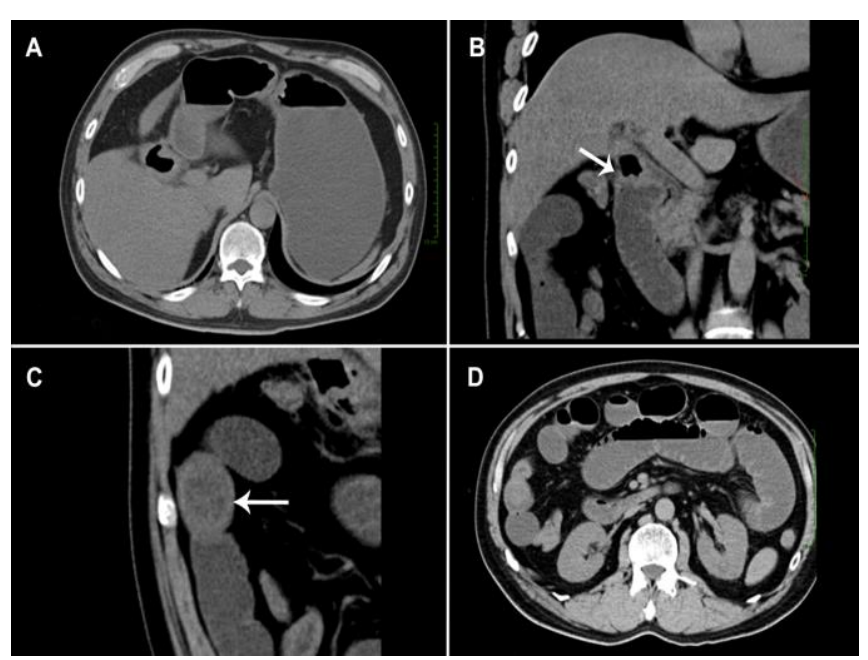

Fig. 2 (Рис. 2)

\section{Fig. 2. Non-enhanced abdominal CT scan.}

A - axial image with dilated stomach and gas within gall bladder, B - reformated coronal image with the site of the cholecystoduodenal fistulae (white arrow),

C - small bowel stone with a mild hiperdense cortex (white arrow), D - marked small bowel dilatation.

\section{Рис. 2. Кт брюшной полости, нативная фаза.}

А - аксиальная плоскости, определяется расширенный желудок и газ в желчном пузыре. В - корональная плоскость, место холецистодуоденального свища (белая стрелка). С - камень в области тонкой кишки с умеренной гиперденсной корковой частью (белая стрелка). D - заметное расширение петель тонкой кишки.
Rigler's triad had been considered as pathognomonic for gallstone ileus, in recent studies only two signs out of the triad are present, with $14-53 \%$ of cases presenting the full criteria [3]. Relevant findings are summarised by imaging method and sensitivity [3, 4, 6-8] (Table 1).

Differential diagnosis.

Differential diagnosis should include internal herniation, adhesions, tumour, volvulus and others [9].

\section{Treatment.}

Initial management begins with the "drip and suck" regimen (nasogastric tube for decompression and intravenous fluids for rehydration) [3]. Management of these patients in every case should be individualised; the approach can be by enterolithotomy, removal of the stone through an enterotomy, without performing a procedure to resolve the fistula or gallbladder disease; it has lower mortality (11.7 vs $16.9 \%)$ than other approaches and is considered a good choice in patients with significant comorbidities, hemodynamic instability, or high-risk surgical dissection [8, 9]. One-stage surgery involves a particular biliary technique (cholecystectomy or cholecystostomy), the closure of the fistula and enterolithotomy; it may be suitable in low-risk patients, young people at risk of subsequent biliary complications or risk of recurrent gallstone ileus. Another therapeutic option is a laparoscopic approach, which requires a qualified surgeon and appropriate instruments, but implies a faster recovery with less morbidity 


\section{RUSSIAN ELECTRONIC JOURNAL OF RADIOLOGY}

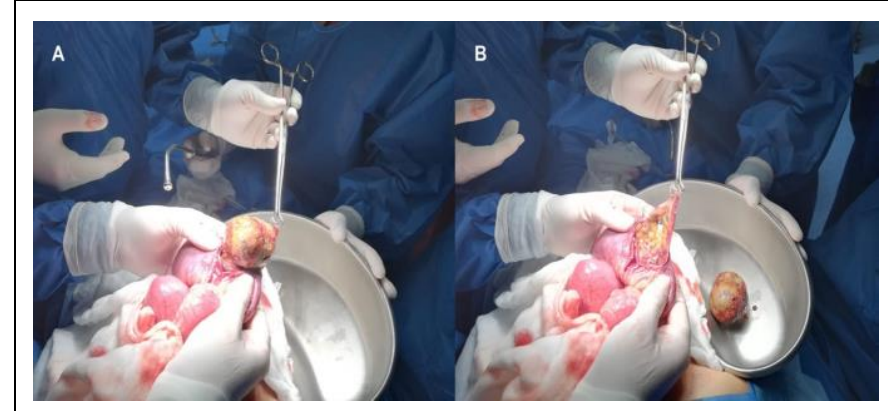

Fig. 3 (Рис. 3)

Fig. 3. Intraoperative photo.

A, B - extraction of the stone by enterolithotomy.

Рис. 3. Интраоперационные фотографии.

А, Б - извцечение камня с помощью энтеролитотомии.

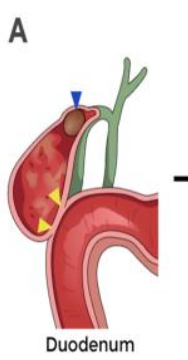

B

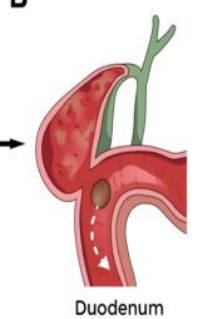

C

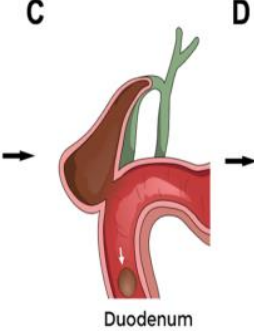

Fig. 4 (Рис. 4)
Fig. 4. Scheme.

A - gallstone in the gallbladder (blue head arrow); there is erosion between gallbladder and duodenum (yellow head arrows). B - cholecystoduodenal fistulae formed, a gallstone passing down the duodenum (dotted white arrow). C - gallstone passed the duodenum (white arrow). D - ectopic gallstone impacting the distal ileum (green arrow).

Рис. 4. Схема.

А - желчный камень в желчном пузыре (синяя стрелка); эрозия между желчным пузырем и двенадцатиперстной кишкой (желтые стрелки на головке). В - сформированный холецистодуоденальный свищ, желчный камень проходит по двенадцатиперстной кишке (пунктирная белая стрелка). С - желчный камень прошел двенадцатиперстную кишку (белая стрелка). D - эктопированный желчный камень, заполняющий дистальный отдел подвздошной кишки (зеленая стрелка).

\begin{tabular}{|c|l|c|c|}
\hline \multicolumn{3}{|c|}{ Table №1. } & \multicolumn{1}{c|}{ Classification of sclerosing encapsulating peritonitis (SEP). } \\
\hline Imaging method & \multicolumn{1}{|c|}{ Findings } & Sensitivity & References \\
\hline $\begin{array}{c}\text { Abdominal } \\
\text { radiography }\end{array}$ & $\begin{array}{l}\text { Rigler's triad: air in the biliary tree (pneumobilia), ectopic } \\
\text { radio-opaque stone, and small bowel obstruction. Air in the } \\
\text { gallbladder may be present. }\end{array}$ & $40-70 \%$ & {$[3,5,6]$} \\
\hline \multirow{2}{*}{ Ultrasonography } & $\begin{array}{l}\text { Pneumobilia, reflective linear echoes, central pneumatosis, } \\
\text { casting posterior acoustic shadowing, reverberation arti- } \\
\text { facts, bowel swelling or peritoneal fluid. }\end{array}$ & $>95 \%$ & {$[5,6]$} \\
\hline CT Scan & $\begin{array}{l}\text { Small bowel obstruction with gallstone(s) at the point of } \\
\text { transition, cholelithiasis (varying degrees of inflammatory } \\
\text { changes around the gallbladder), and presence of intralu- } \\
\text { minal gas in the gallbladder; pneumobilia or bilio-digestive } \\
\text { fistula. }\end{array}$ & $90-93 \%$ & {$[5,7,8]$} \\
\hline
\end{tabular}

and mortality [9].

Clinical presentation.

In the context of recurrent cholecystitis, the inflammation in the gallbladder and the pres sure effect of the gallstone leads to erosion and consequently causes fistula formation with the adjacent gastrointestinal tract [2]. The cholecystocholedochal fistula often presents with abdominal pain, fever and jaundice, without any pathognomonic pattern, which hinders clinical diagnosis [6].

Gallstone ileus is a rare complication associated with recurrent subclinical or milder episodes of cholecystitis; the patient presents with signs and symptoms of bowel obstruction. Intestinal obstruction is the outcome of an impacted ec- 


\section{RUSSIAN ELECTRONIC JOURNAL OF RADIOLOGY}

topic gallstone, usually in the distal ileum (Fig. 4) [4].

\section{Complications.}

Correct evaluation of gallstone size is important, since those smaller than $2 \mathrm{~cm}$ may be dangerous as they may become larger by accretion while descending the intestinal canal and thus produce reflex spasm or volvulus [4]. Surgical management (typically elderly, frail with multiple comorbidities) has a high risk of morbidity and mortality, and efforts are often directed at less invasive management [3].

In conclusion, the use of radiological imaging is invaluable in the diagnosis of gallstone ileus, hence the importance to make an early suspi-

\section{References:}

1. Crosen M, Ghattas P, Sandhu R. Large bowel obstruction secondary to gallstones. J Surg Case Rep. 2021; 2021 (5): rjab137.

2. Tsang CF. A rare case of gallstone ileus-the unanswered question. J Surg Case Rep. 2021; 2021 (4): rjab164.

3. Chang L, Chang M, Chang HM, Chang AI, Chang F. Clinical and radiological diagnosis of gallstone ileus: a mini review. Emerg Radiol. 2018; 25 (2): 189-96.

4. Aldo C, Lorenzo M, Olgerta L, Alberto C, Licia U, Melchiore G. Rolling in the Deep: Imaging Findings and Diagnostic Pearls in Gallstone Meus. Surg Res Pract. 2020; 2020: 1421753.

5. Macfarlane JA. Recurrent gall-stone ileus. Br Med J. 1953; 2 (4835): 544-5.

6. Chawla A, Bosco JI, Lim TC, Srinivasan S, Teh HS, Shenoy cion in elderly patients with chronic cholecystitis and avoid indiscriminate use of antibiotics or analgesics that could mask the diagnosis.

Conflicts of Interest.

The authors declare that there is no conflict of interest regarding the publication of this article.

Acknowledgements.

F.S.R. was a research fellow at HGMEL under the supervision of E.R.V. in 2021.

Funding Statement.

This research received no specific grant from any funding agency in the public, commercial, or not-for-profit sectors.

JN. Imaging of acute cholecystitis and cholecystitis-associated complications in the emergency setting. Singapore Med J. 2015; 56 (8): 438-43; quiz 44.

7. Lassandro F, Gagliardi N, Scuderi M, Pinto A, Gatta G, Mazzeo R. Gallstone ileus analysis of radiological findings in 27 patients. Eur J Radiol. 2004; 50 (1): 23-9.

8. Jakubauskas M, Luksaite R, Sileikis A, Strupas K, Poskus T. Gallstone Ileus: Management and Clinical Outcomes. Medicina (Kaunas). 2019; 55 (9).

9. Ploneda-Valencia CF, Gallo-Morales $M$, Rinchon C, NavarroMuniz E, Bautista-Lopez CA, de la Cerda-Trujillo LF, et al. Gallstone ileus: An overview of the literature. Rev Gastroenterol Mex. 2017; 82 (3): 248-54. 